\title{
IMMUNOHISTOCHEMICAL IDENTIFICATION OF PLASMA PROTEIN DEPOSITS IN THE WALL OF LENTICULOSTRIATE ARTERIES IN PATIENTS WITH LONG-STANDING HYPERTENSION, WITH AND WITHOUT LIPOHYALINOSIS
}

\author{
Magda Rocha Andrade, José Eymard Homem Pittella
}

\begin{abstract}
Purpose: To investigate, through an immunohistochemical method, whether there is deposition of plasma proteins in the wall of lenticulostriate, cortical and leptomeningeal arteries of hypertensive patients, with and without lipohyalinosis. Method: Forty patients with essential hypertension were selected at random, 20 with lipohyalinosis in the lenticulostriate arteries ( $\mathrm{HH}$ group) and 20 without lipohyalinosis ( $\mathrm{H}$ group), matched with 20 normotensive controls (C group). Results: Plasma protein deposits were identified in eight patients (40\%) in the $\mathrm{C}$ group, in 15 patients $(75 \%)$ in the $\mathrm{H}$ group, and in all 20 patients $(100 \%)$ in the $\mathrm{HH}$ group, the difference being significant for the $\mathrm{H}$ group and highly significant for the $\mathrm{HH}$ group, as compared with the $\mathrm{C}$ group. In all groups, the distribution of plasma protein deposits, subendothelial in normal arteries, and diffuse, irregular in the wall of arteries with lipohyalinosis, was more frequent in the lenticulostriate arteries of the putamen. Conclusion: Deposition of plasma proteins in the lenticulostriate arteries seems to be relatively frequent in normotensive individuals, starting in middle age. Such process appears to be intensified by hypertension, especially in individuals with lipohyalinosis.
\end{abstract}

KEY WORDS: hypertension, hypertensive angiopathy, lenticulostriate arteries, lipohyalinosis, plasma protein deposits.

\begin{abstract}
Identificação imuno-histoquímica de depósitos de proteínas plasmáticas na parede das artérias lentículoestriadas em pacientes com hipertensão arterial de longa duração, com e sem lipo-hialinose

Resumo - Propósito: Investigar, por meio de método imuno-histoquímico, a deposição de proteínas plasmáticas na parede das artérias lentículo-estriadas, corticais e leptomeníngeas em pacientes com hipertensão arterial, com e sem lipo-hialinose. Método: Quarenta pacientes com hipertensão arterial foram selecionados aleatoriamente, sendo 20 com lipo-hialinose nas artérias lentículo-estriadas (grupo HH) e 20 sem lipo-hialinose (grupo H), pareados com 20 controles normotensos (grupo C). Resultados: Depósitos de proteínas plasmáticas foram identificados em oito pacientes (40\%) do grupo C, em 15 pacientes (75\%) do grupo $\mathrm{H}$ e em todos os 20 pacientes $(100 \%)$ do grupo $\mathrm{HH}$, a diferença sendo significativa para o grupo $\mathrm{H}$ e altamente significativa para o grupo $\mathrm{HH}$, quando comparada com o grupo C. Em todos os grupos, a distribuição dos depósitos de proteínas plasmáticas, subendotelial em artérias normais e difusa, irregular, na parede das artérias com lipo-hialinose, foi mais freqüente nas artérias lentículo-estriadas do putâmen. Conclusão: A deposição de proteínas plasmáticas nas artérias lentículo-estriadas parece ser um fenômeno relativamente freqüente em indivíduos normotensos, a partir da meia-idade. Tal processo parece ser intensificado pela hipertensão arterial, particularmente naqueles pacientes com lipo-hialinose.
\end{abstract}

PALAVRAS-CHAVE: hipertensão arterial, angiopatia hipertensiva, artérias lentículo-estriadas, lipo-hialinose, depósitos de proteínas plasmáticas.

Hypertension is an important public health problem in developed and developing countries, affecting $26 \%$ of the adult population in $2000^{\prime}$. The repercussions of hy- pertension are observable in several organs, particularly the heart, kidneys, brain, and retina ${ }^{2}$. Hypertensive changes in the brain may be acute, chronic, or both. Not in-

Laboratory of Neuropathology, Department of Pathology and Forensic Medicine, School of Medicine, Federal University of Minas Gerais, Belo Horizonte MG, Brazil. This study was supported by grant 302036/76 (Dr. JEH Pittella) from Conselho Nacional de Desenvolvimento Científico e Tecnológico (CNPq).

Received 28 July 2008, received in final form 30 October 2008. Accepted 9 December 2008.

Dr. José Eymard Homem Pittella - Rua dos Otoni 712 / 304 - 30150-270 Belo Horizonte MG - Brasil. E-mail: pittella@medicina.ufmg.br 
frequently, acute changes, including intracerebral hemorrhage and hypertensive encephalopathy are superimposed on chronic changes, such as lacunar infarction and diffuse white matter lesion ${ }^{3,4}$. A variety of pathological changes of cerebral small arteries are routinely found in these hypertensive brains, some of which are considered to be specific for hypertension and appear to be causally related to brain injury. For that reason, these vascular lesions are often called hypertensive angiopathy or hypertensive cerebral small vessel disease ${ }^{4,5}$. Lipohyalinosis, a destructive vessel wall lesion, is the small vessel change of major pathogenetic significance to intracerebral hemorrhage and lacunar infarction. In acute cases, such vascular change is evidenced by fibrinoid necrosis and, in healing stage, it is characterized by a more homogeneous and less structured eosinophilic thickened arterial wall with fibrinoid change and mural foam cell infiltration ${ }^{4-11}$. With time, the fibrinoid material is replaced by fibrosis and when the fibroblasts disappear the fibrosis acquires a collagenous sclerotic aspect. These changes are often associated with aneurysmal dilatation of the vessel wall and mild perivascular lymphocytic cuffing. Lipohyalinosis is found in longstanding hypertension, affects perforating vessels measuring less than $300 \mu \mathrm{m}$ in diameter, is segmental in nature, and preferentially involves the branches of the lenticulostriate arteries.

The genesis of these hypertensive vascular lesions has been correlated with the passage of plasma proteins into the vessel wall ${ }^{9}$. This process has been experimentally demonstrated in the brain of rats, including spontaneous hypertensive and stroke-prone spontaneously hypertensive rats, with the use of various tracers, such as horseradish peroxidase ${ }^{12-14}$, in addition to immunohistochemical techniques, with the staining of plasma proteins ${ }^{13,15,16}$. In these studies, the increase in permeability was correlated with areas of blood-brain barrier breakdown and intramural infiltration of plasma proteins through pinocytotic vesicles and between the junctions of intimal endothelial cells ${ }^{12-14,16,17}$. These facts indicate that the hypertensive stimulus, through elevated hydrostatic pressure, would lead to endothelial dysfunction and increased permeability, allowing fibrinogen and other plasma constituents to pass through the damaged endothelial layer. Such changes would be associated with various changes in smooth-muscle cells and fibroblasts of the vessel wall - cell growth, cell death, cell migration, and production or degradation of extracellular matrix (e.g., collagen and elastin). This process, known as vascular remodeling, is usually adaptive and occurs in response to hemodynamic stimuli ${ }^{18}$.

Since there are no studies on the presence of plasma protein deposits in the cerebral vessel wall in hypertensive patients, we investigate, through an immunohistochemical method, whether there is deposition of plas- ma proteins on the wall of lenticulostriate, cortical and leptomeningeal arteries of hypertensive patients with and without lipohyalinosis, in different age groups, matched with normotensive controls.

\section{METHOD}

After receiving institutional review board approval, forty patients with essential hypertension, aged 31 to 86 years, were selected at random from the neuropathological reports of the files of the Laboratory of Neuropathology, Department of Pathology, Federal University of Minas Gerais Medical School, Belo Horizonte, Brazil, covering the period between 1976 and 1996. All of the patients came from Hospital das Clínicas (a general hospital) of the Minas Gerais Federal University. Of these 40 cases, 20 showed lipohyalinosis in the small arteries of the basal ganglia, making up the hypertension group with hyalinosis $(\mathrm{HH})$, and 20 did not have such lesion, forming the group referred to simply as the hypertension group $(\mathrm{H})$. These two groups were then agematched with a third group, the control group (C), which included 20 patients known to be normotensive.

The presence or absence of essential hypertension in the 60 patients was determined with basis on analysis of the autopsy requests containing the patients' history and on review of the macro- and microscopic pathological examination reports. Patients were defined as having benign hypertension during life if the following criteria were met ${ }^{19,20}$ : a documented clinical diagnosis of untreated arterial hypertension (blood pressure more than $160 / 90 \mathrm{~mm} \mathrm{Hg}$ ); macroscopic evidence of left ventricular hypertrophy, without other cause; microscopic features of benign nephrosclerosis (presence of intimal fibroelastosis and hyalin arteriolosclerosis). The classification of the hypertension into malignant was made in accordance with clinical and histopathological criteria already well established in the literature ${ }^{20}$ : diastolic blood pressure more than $120 \mathrm{~mm} \mathrm{Hg}$; microscopic changes of malignant nephrosclerosis (presence of intimal myxoid fibroplasia/onion skinning and arteriolar fibrinoid necrosis).

For studying the lenticulostriate, cortical and leptomeningeal arteries, paraffin-embedded fragments from the basal ganglia (at the level of the optic chiasma and/or mammillary body) and one such fragment from the cerebral cortex (preferentially the cortex of the superior frontal gyrus) were selected from each case. Eight serial histologic sections were obtained from these blocks and stained with Hematoxylin-Eosin (H\&E), Weigert-Van Gieson stain, and by the immunoperoxidase method for identification of the plasma proteins being investigated. The presence or absence of lipohyalinosis in lenticulostriate arteries - the criterium for classification into the two groups of hypertensive patients - was previously determined through an average number of 15 consecutive histologic sections from the basal ganglia fragments. Lipohyalinosis was characterised by fibrinoid necrosis of the vessel wall or by a more homogeneous and less structured eosinophilic thickened arterial wall with fibrinoid change and/ or collagenous sclerosis (Fig 1A-B) 4,5 . 
As concerns the immunohistochemical technique, non-specific cross-reactions were blocked with the application of normal goat serum diluted 1:40 in phosphate-buffered solution (PBS). All primary antibodies used were polyclonal, produced in rabbits against one of the human plasma proteins investigated in this study. The incubation times and dilutions were as follows: 20 minutes after the application of IgA (1:600) and IgG (1:1050); 30' for C3 (1:100) and IgM (1:750); and 60' for albumin (1:4500) and fibrinogen (1:1600). Goat anti-rabbit immunoglobulin (rabbit antiimmunoglobulin) diluted 1:150 was used as a secondary antibody, followed by application of the peroxidase-antiperoxidase (PAP) complex produced in rabbits, diluted 1:100. Revealing of the reaction was done with 0.50 milligrams of 3.3'-diaminobenzidine (DAB) tetrahydrochloride. For counterstaining, Harris' hematoxylin was used. Negative controls for the immunohistochemical reaction were done by using PBS in place of the primary antibody. Immunoreactivity was inferred as being negative when immunoreaction was absent in the plasma contained in the cerebral blood vessels and absent at sites that showed positive immunoreactivity when subjected to the application of an anti-plasma protein antibody.

All primary antibodies used (except for albumin staining), the secondary antibody and the PAP complex were purchased from Dakopatts, Glostrup, Denmark.

The human anti-albumin was purchased from Sigma Chemicals, St. Louis, USA. The DAB used was supplied by these two laboratories.

On microscopic examination of the cerebral small arteries, performed with X100 magnification, there were noted the number (whether corresponding to distinct branches or different segments of the same artery) and severity of each type of vascular lesion found, as well as the topography of the affected vessels (e.g., putamen, globus pallidus, leptomeninges). Lipohyalinosis was graded as: discrete (+), when affecting only one segment of the vessel wall; moderate (++), when involving the entire circumference of the vessel wall; or severe (+++), when, in addition to affecting the entire circumference of the vessel wall, it caused some degree of obstruction of the vascular lumen.
In addition to the topography and number of arteries involved, the location of plasma protein deposits in the arterial wall was also noted. The location of plasma protein deposits in the arterial wall was classified as segmental subendothelial, as the deposit was located beneath the endothelium, occupying a smaller or larger segment of the wall. In the HH group, the distribution of plasma protein deposits in arteries with lipohyalinosis was evaluated as focal or diffuse, depending on the smaller or larger degree of immunostaining of the vessel wall affected with lipohyalinosis. The histological sections were analyzed by the two authors using a multiheaded microscope, blinded to clinical data and unawared of the groups to which the patients belonged.

For comparing the differences in mean age between the various groups, the variance analysis was made. The differences in the frequency of the vascular changes between the various groups, expressed in percentages, were compared using the Chi-square test $\left(\chi^{2}\right)$ or Fisher's exact test, as appropriate. $p \leq 0.05$ was accepted as significant, and $\mathrm{P} \leq 0.01$ was considered as highly significant.

\section{RESULTS}

The ages of the patients are shown in Table 1. The ages of the 20 patients in the $C$ group varied from 33 to 84 years (mean $58.3 \pm 14.4$ years). In the $\mathrm{H}$ group, the age range was 31 to 86 years (mean 59.1 \pm 14.1 ). In the $\mathrm{HH}$ group, the patients' ages varied from 33 to 84 years (mean $58.0 \pm 12.8$ years). About half of the patients in each group were over 60 years of age, totaling 31 out of the 60 patients. A comparison of the mean ages between the three groups showed no significant difference, evidencing the homogeneity of the groups. Thirty $(75 \%)$ of the patients had benign hypertension (17 in the $\mathrm{H}$ group and 13 in the $\mathrm{HH}$ group), four (10\%) had malignant hypertension (two in each group), and six (15\%) showed malignant lesions superimposed on the benign hypertension (one in the $\mathrm{H}$ group and five in the $\mathrm{HH}$ group). Therefore, about $1 / 3$ (7) of the patients in the $\mathrm{HH}$ group had malignant hypertension, either isolated or superimposed on the benign hypertension.

Table 1. Age distribution of the patients in the control group (C), hypertensive group without lipohyalinosis $(H)$, and hypertensive group with lipohyalinosis $(\mathrm{HH})$.

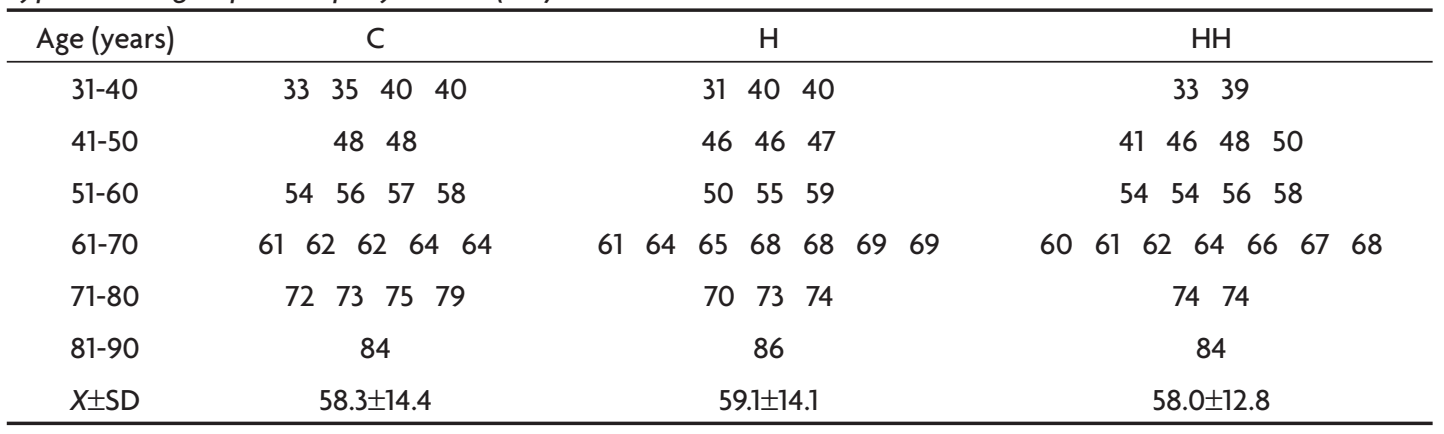

$X$ mean; SD, standard deviation. 


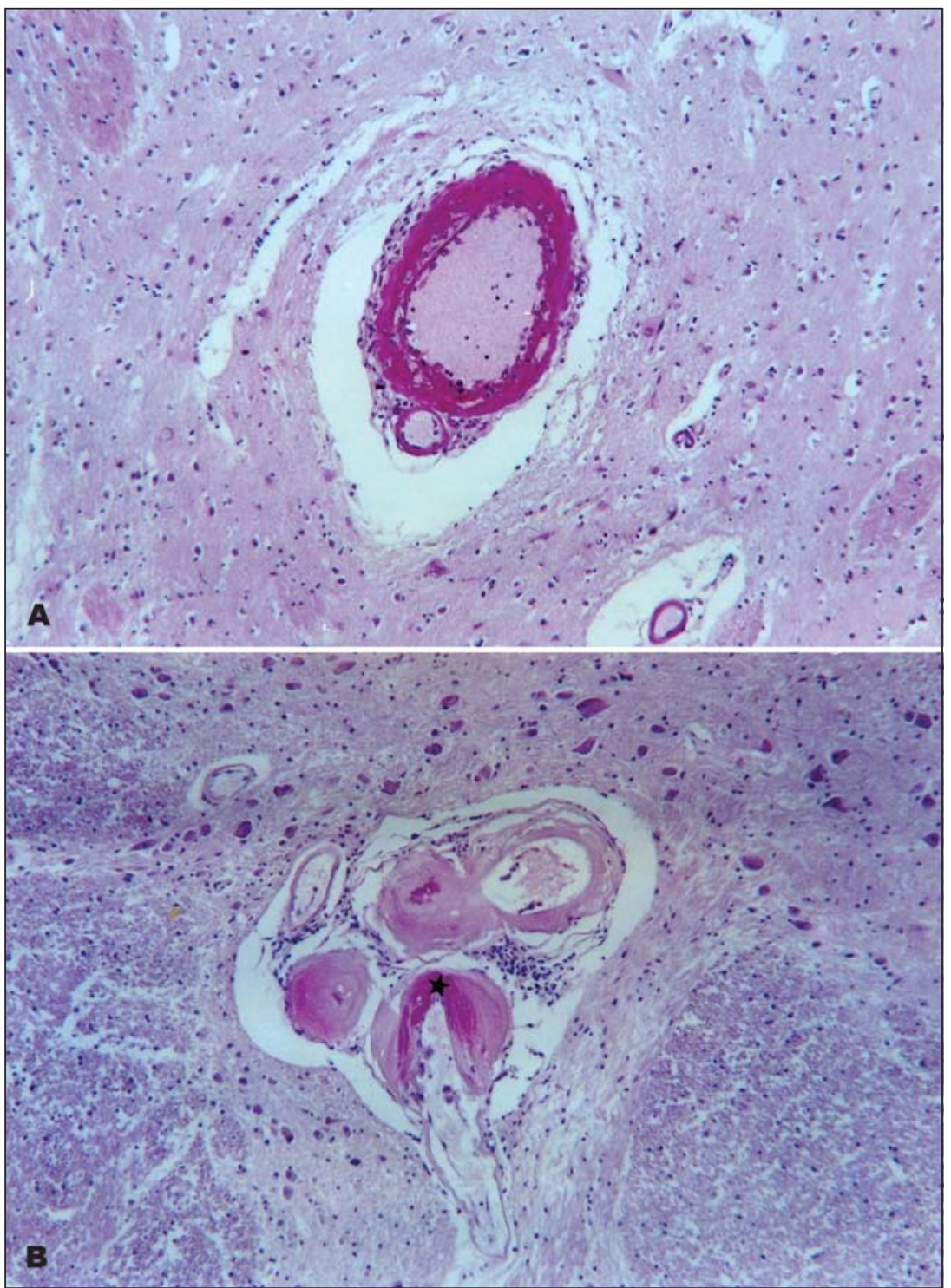

Fig 1. Hypertensive group with lipohyalinosis. Lenticulostriate artery with severe lipohyalinosis. (A) Acute stage. Fibrinoid necrosis of the vessel wall. Note mild perivascular lymphocytic cuffing. H\&E. (B) Healing stage. Vessel wall thichening by homogeneous and less structured eosinophilic material with fibrinoid necrosis (asterisk). Note perivascular cuffing. H\&E. Approx. X100.
In the $\mathrm{HH}$ group, lipohyalinosis (Fig 1A-B) predominated in the putamen (42 arteries). It was found in such location in 19 patients (95\%) in this group and in a much smaller number ( 6 arteries) at other sites. There was a wide variation in the severity of lipohyalinosis, not only among the patients themselves, but also between different arteries seen in the same case, with predominance of the moderate and severe degrees.

Segmental subendothelial deposits with the histologic characteristics of plasma were already evident with the utilization of routine stains such as H\&E (Fig 2A), with the presence of plasma proteins being confirmed by positive immunoreactivity for the proteins investigated (Fig 2B). In the arteries with lipohyalinosis, irregular diffuse plasma protein deposits in the vessel wall (Fig 3A-B) occurred in almost all cases. Only a few vessels with lipohyalinosis showed irregular focal distribution of plasma protein de- posits. In regard to the investigated plasma proteins, no great differences were observed in the frequency and intensity of staining of the immunoreaction. However, the immunostaining for $\mathrm{C} 3$ fraction of the complement was almost always negative, even in areas that stained positively for other plasma proteins. Where present at all, it usually stained less intensely.

Plasma protein deposits in the arterial wall was observed in eight patients (40\%) in the $\mathrm{C}$ group, in 15 patients (75\%) in the $\mathrm{H}$ group, and in all patients $(100 \%)$ in the $\mathrm{HH}$ group, the difference being significant between the $\mathrm{H}$ group and the $\mathrm{C}$ group, and highly significant between the $\mathrm{HH}$ group and the $\mathrm{C}$ group (Table 2). The frequency of plasma protein deposits was significantly higher in the $\mathrm{HH}$ group, as compared with the $\mathrm{H}$ group. In the $\mathrm{C}$ group, no significant difference in mean age was found between the patients with and without plasma protein deposits. 


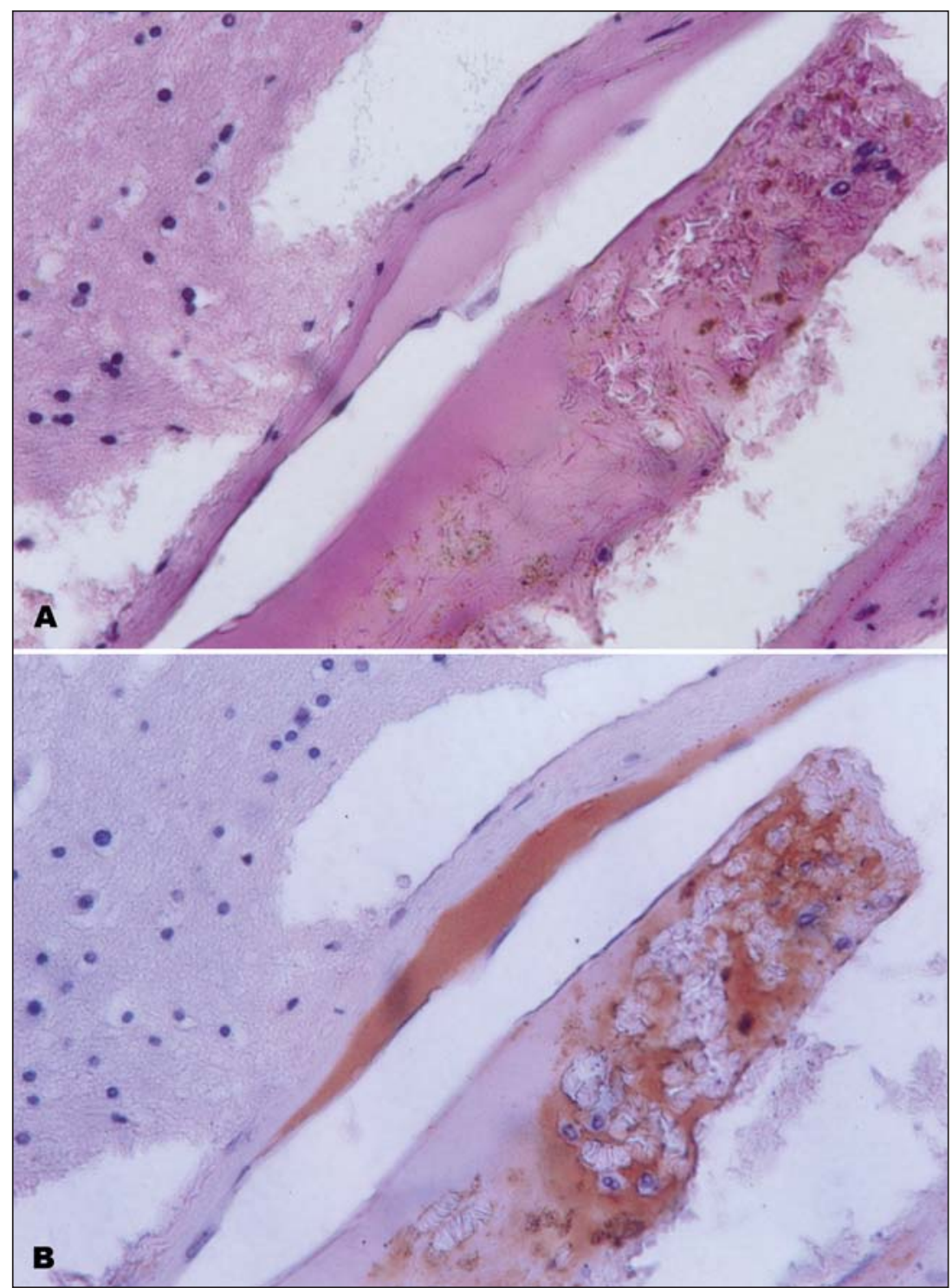

Fig 2. Hypertensive group without lipohyalinosis. Normal lenticulostriate artery. Segmental subendothelial plasma protein deposit. (A) H\&E. (B) Immunoperoxidase (immunostaining for fibrinogen). Approx. X400.

Table 2. Frequency of plasma protein deposits in the wall of lenticulostriate, cortical and leptomeningeal arteries, and mean ages of the patients in the control group (C), hypertensive group without lipohyalinosis $(H)$, and hypertensive group with lipohyalinosis $(\mathrm{HH})$.

\begin{tabular}{ccccccccc}
\hline & \multicolumn{2}{c}{ Presence of plasma protein deposits } & & \multicolumn{3}{c}{ Absence of plasma protein deposits } \\
\cline { 2 - 4 } \cline { 6 - 8 } & $\mathrm{n}$ & $\%$ & mean age and SD & & $\mathrm{n}$ & $\%$ & mean age and SD \\
\hline $\mathrm{C}$ & 8 & $40(1)$ & $63.8 \pm 12.6$ & & 12 & 60 & $54.6 \pm 14.9$ \\
$\mathrm{H}$ & 15 & $75(2)$ & $58.7 \pm 15.0$ & & 5 & 25 & $60.2 \pm 12.6$ \\
$\mathrm{HH}$ & 20 & $1100(3)$ & $58.0 \pm 12.8$ & & & & \\
Total & 43 & & & & & 17 & & \\
\hline
\end{tabular}

$\mathrm{n}$, number of cases; SD, standard deviation; Difference is significant ( $\mathrm{p} \leq 0.05)$ between (1) and (2), and (2) and (3); Difference is highly significant ( $p \leq 0.01)$ between (1) and (3).

In the hypertensive groups, plasma protein deposits occurred more frequently in patients in younger age groups, as compared with the $C$ group. However, there was no significant difference in mean age between the $\mathrm{C}$ group and the hypertensive patients with plasma protein deposits. However, seven of the eight patients with plasma protein deposits in the $\mathrm{C}$ group were over 54 years of age.

In all three groups, the arteries with segmental suben- 


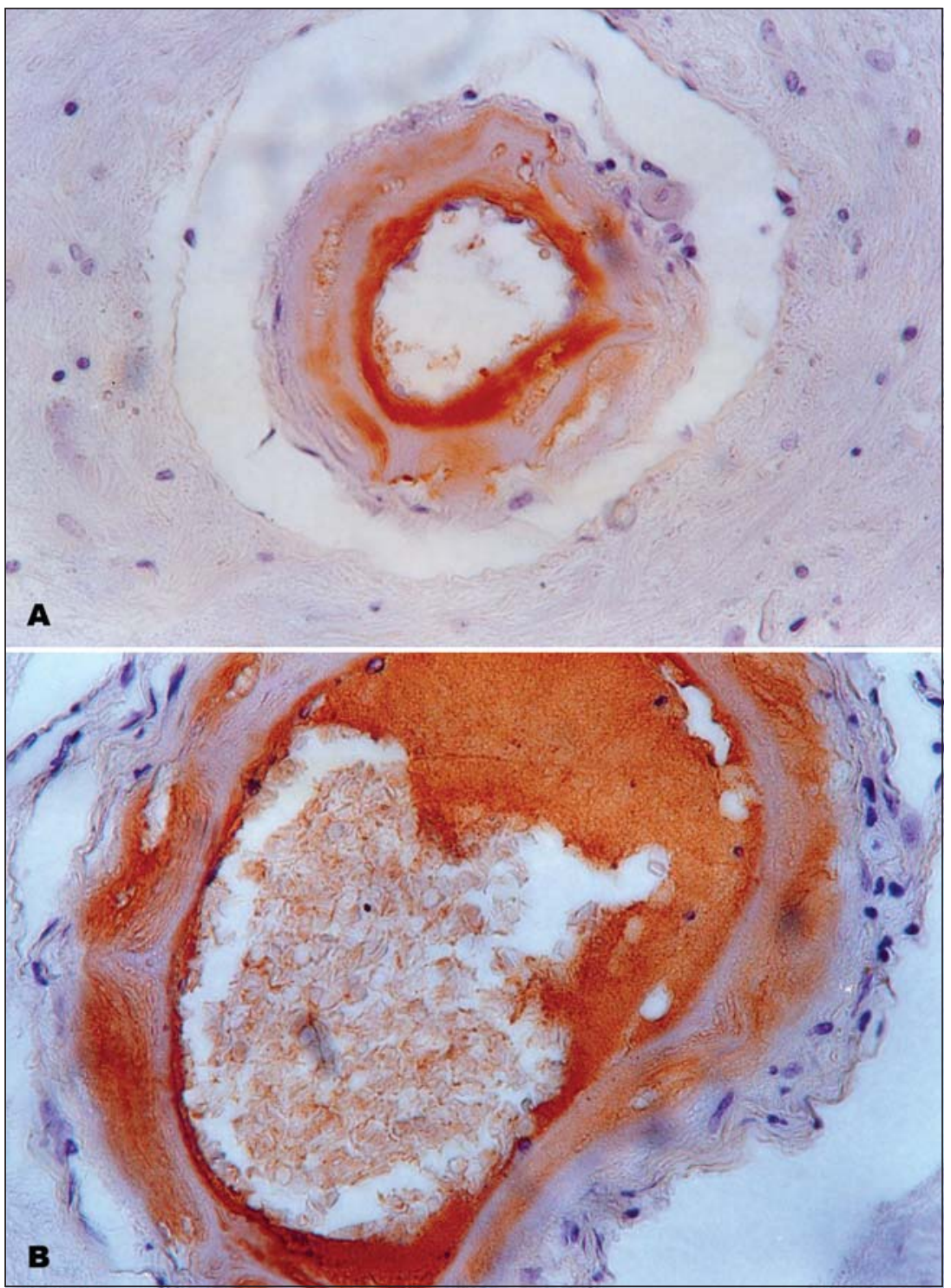

Fig 3. Hypertensive group with lipohyalinosis. Lenticulostriate artery with lipohyalinosis. Irregular diffuse plasma protein deposit in the vessel wall. Immunoperoxidase. (A) Immunostaining for fibrinogen. (B) Immunostaining for IgM. Approx. X400 dothelial plasma protein deposits and those with lipohyalinosis that showed plasma protein deposits had a similar topographic distribution. The arteries in the putamen showed the highest frequency of plasma protein deposits (118 arteries, of which 85 with subendothelial deposits, and 33 with lipohyalinosis), followed by the leptomeningeal arteries ( 20 with subendothelial deposits) and by a small number of arteries in other regions, giving a total of 162 arteries with plasma protein deposits. Of these 162 arteries, 20, all with subendothelial deposits, belonged to the $C$ group, 38, all with subendothelial deposits, to the $\mathrm{H}$ group, and 104 to the HH group (67 with subendothelial deposits, and 37 with lipohyalinosis). Even excluding the arteries with lipohyalinosis that showed plasma protein deposits (37 arteries), the $\mathrm{HH}$ group showed more than three times as many arteries (67) with subendothelial plasma protein deposits, as compared with the $C$ group ( 20 arter- ies). The $\mathrm{H}$ group, on the other hand, showed about twice as many arteries (38) with subendothelial plasma protein deposits, as compared with the $C$ group (20 arteries).

\section{DISCUSSION}

The peak age of onset of essential hypertension is between 30 and 40 years, and most of the patients, even if not treated, will survive for about 25 years, in average, after the disease is diagnosed ${ }^{2,21}$. Such fact explains why, similarly to our investigation, the studies based on autopsy data for hypertensive patients show a more concentration of cases in patients over 60 years of age ${ }^{22-24}$. It also explains why, in the hypertensive groups and, therefore, also in the matched $C$ group, about half of the selected patients were between 61 and 70 years of age. Due to this prolonged evolution of essential hypertension, the morphologic arterial changes in various organs, except in malignant 
hypertension, develop progressively over the years after onset of the disease, such changes being more frequent and more severe in the brain, starting at the age of $50^{25}$.

In our investigation, $75 \%$ of the patients had benign hypertension, $15 \%$ had the malignant form superimposed on the benign hypertension, and $10 \%$ had malignant hypertension. Therefore, $25 \%$ of the patients studied showed pathological changes compatible with the malignant hypertension. This is in disagreement with the literature reviewed, which reports only $10 \%$ of hypertensives as having malignant hypertension, either isolated or, more frequently, superimposing on the benign hypertension as the disease progresses ${ }^{26,27}$. The higher frequency of malignant hypertension in our study may be due to the pre-selection of lipohyalinosos in the lenticulostriate arteries as a criterium for classification into the $\mathrm{HH}$ group. About $1 / 3$ of the patients in this group had malignant hypertension, either isolated or superimposed on the benign hypertension.

The presence or absence of lipohyalinosis in lenticulostriate arteries in consecutive histologic sections from the basal ganglia was the criterium used for distribution of the hypertensive patients into the two groups. The necessity of using consecutive sections for diagnosing the lipohyalinosis is due to the segmental nature of the lesions. Some authors recommend that as many as 20-30 consecutive histologic sections from the basal ganglia being obtained for such diagnosis ${ }^{9}$. Although no arterial lesion is totally specific of hypertension, arteriolar hyalinosis and, sometimes, hyalinosis in small arteries of various organs is, according to several authors, the commonest and most characteristic lesion of benign essential hypertension ${ }^{28}$, hence the study of this lesion also in the brain being of great interest.

As concerns the histology of the lipohyalinosis seen in the patients in the $\mathrm{HH}$ group, in brain vessels this lesion prefers the media and usually the small arteries ${ }^{8,9}$, unlike what occurs at other sites (in the kidneys, for example, the hyaline deposits are preferentially located in the intima and more often involve the arterioles and, sometimes, the renal small arteries). To some authors, arteriolar hyalinosis in various organs may occur in normotensive individuals and is related with advanced age. However, in the present study, lipohyalinosis in the cerebral small arteries was found in none of the 20 patients in the $C$ group, not even in the five patients over 70 years of age. This is probably due to the fact that, unlike the arterioles and contrary to what occurs in the spleen, kidney, pancreas, liver, and adrenal gland ${ }^{22,25,27-29}$, the cerebral small arteries are not affected by lipohyalinosis during aging.

Lipohyalinosis was predominantly distributed in the lenticulostriate arteries of the putamen and its presence also correlated with the greater severity of the form of hypertension found. About one third of the patients in the $\mathrm{HH}$ group had malignant hypertension or the malignant form superimposed on the benign hypertension, whereas only three patients (15\%) in the $\mathrm{H}$ group had malignant hypertension. Rothemund and Frische ${ }^{8}$ had already reported the more frequent presence of lipohyalinosis in the patients with higher blood pressure levels.

Positive immunoreactivity for plasma proteins in the wall of cerebral small arteries, even though it occurred also in the $C$ group, was more frequent in the hypertensive groups. No significant difference in mean age was detected between the normotensives with and without subendothelial plasma protein deposits. However, seven of the eight patients in the $\mathrm{C}$ group in which plasma protein deposits were observed were over 54 years of age. This suggests that, regardless of blood pressure levels, the deposition of plasma proteins in the arterial intima appears to be a part of old age phenomena. On the other hand, even though there was no significant difference in mean age between the hypertensive patients with and without plasma protein deposits, such vascular changes were more frequently found in younger patients, as compared with the $C$ group. This indicates that hypertension could cause the earlier appearance of subendothelial plasma protein deposits.

Our study showed also the presence of plasma protein deposits in the vessel wall of all arteries with lipohyalinosis and this change was equally associated with the more frequent involvement of a larger number of arteries with subendothelial plasma protein deposits, as compared with the $\mathrm{H}$ and $\mathrm{C}$ groups, indicating that subendothelial plasma protein deposits and lipohyalinosis are correlated. One other fact that confirms the close interrelationship between subendothelial plasma protein deposition and lipohyalinosis is that plasma protein deposits, similarly to lipohyalinosis, were more frequent in the lenticulostriate arteries of the putamen. The reason for the more frequent involvement of these arteries as compared with the leptomeningeal and cerebral cortical arteries is not known. However, a possible explanation could be the manner in which the lenticulostriate arteries originate. The lenticulostriate arteries are small-caliber vessels and arise at a straight angle from the middle cerebral artery, in the lateral sulcus, and to a smaller extent, from the anterior cerebral artery. The anterior and middle cerebral arteries are large-caliber vessels, constituting terminal branches of the internal carotid artery. The middle cerebral artery is the larger of the two and considered to be a direct continuation of the internal carotid artery ${ }^{30}$. There is a rather abrupt transition from a large-sized cerebral artery to one of a small caliber, causing the latter to be subjected to the impact of high pressure parent arteries, which would account for the increased permeability of the vessel wall". 
To summarize, the findings from this investigation and the data reported in the literature allow us to present the following conclusions. In the $\mathrm{C}$ group the presence of plasma protein deposition occurred in more aged patients. In the hypertensive groups, such vascular changes were seen in a larger number of patients, including younger individuals than those in the $C$ group, and affected a larger number of vessels. These findings indicate that the increase in blood pressure may be responsible for the higher incidence of subendothelial plasma protein deposition, even though such changes may be a part of the vascular lesions related with aging. The association between lipohyalinosis and the more frequent involvement of a larger number of arteries with subendothelial plasma protein deposits and its occurrence, in similar locations, particularly in the lenticulostriate arteries of the putamen, suggest that subendothelial plasma protein deposition may have a role in the pathogenesis of lipohyalinosis.

\section{REFERENCES}

1. Kearney PM, Whelton M, Reynolds K, Muntner P, Whelton PK, He J. Global burden of hypertension: analysis of worldwide data. Lancet 2005;365:217-223

2. Williams GH. Hypertensive vascular disease. In: Isselbacher KJ, Braunwald E, Wilson JD, Martin JB, Fauci AS, Kasper DL (Eds). Harrison's principles of internal medicine, $13^{\text {th }}$ Ed. New York: McGraw-Hill, 1994:1116-1131.

3. Stoner JD, Parker JC Jr. The effects of hypertension on the nervous system. Ann Clin Lab Sci 1991;21:147-152.

4. Lammie GA. Hypertensive cerebral small vessel disease and stroke. Brain Pathol 2002;12:358-370.

5. Kalimo H, Kaste M, Haltia M. Vascular diseases. In: Graham DI, Lantos PL (Eds). Greenfield's neuropathology, $7^{\text {th }} \mathrm{Ed}$. Vol 2. London: Arnold, 2002:281-355.

6. Fisher $\mathrm{CM}$. The arterial lesions underlying lacunes. Acta Neuropathol 1969;12:1-15.

7. Fisher CM. Pathological observations in hypertensive cerebral hemorrhage. J Neuropathol Exp Neurol 1971;30:536-550.

8. Rothemund E, Fische M. Klinisch-pathologische Studie zur Entstehung der intracerebralen Gefässhyalinose bei Hypertonie. Arch Psychiatr Nervenkr 1973;217:195-206.

9. Zülch KJ. Cerebrovascular pathology and pathogenesis as a basis of neuroradiological diagnosis. In: Diethelm L, Heuck F, Olsson O, Strnad F, Vieten H, Zuppinger A (Eds). Handbuch der medizinischen Radiologie. Band XIV, Teil 1A, Berlin: Springer Verlag, 1981:1-192.
10. Lammie GA. Pathology of small vessel stroke. Br Med Bull 2000;56: 296-306.

11. Sutherland GR, Auer RN. Primary intracerebral hemorrhage. J Clin Neurosci 2006;13:511-517.

12. Westergaard E, van Deurs B, Brondsted HE. Increased vesicular transfer of horseradish peroxidase across cerebral endothelium, evoked by acute hypertension. Acta Neuropathol 1977;37:141-152.

13. Nag S. Cerebral changes in chronic hypertension: combined permeability and immunohistochemical studies. Acta Neuropathol 1984;62: 178-184.

14. Suzuki K, Masawa N, Takatama M. The pathogenesis of cerebrovascular lesions in hypertensive rats. Med Electron Microsc 2001;34:230-239.

15. Fredriksson K, Auer RN, Kalimo H, Nordborg C, Olsson Y, Johansson BB. Cerebrovascular lesions in stroke-prone spontaneously hypertensive rats. Acta Neuropathol 1985;68:284-294.

16. Fredriksson K, Nordborg C, Kalimo H, Olsson Y, Johansson BB. Cerebral microangiopathy in stroke-prone spontaneously hypertensive rats: an immunohistochemical and ultrastructural study. Acta Neuropathol 1988;75:241-252

17. Hazama F, Ozaki T, Amano S. Scanning electron microscopic study of endothelial cells of cerebral arteries from spontaneously hypertensive rats. Stroke 1979;10:245-252.

18. Gibbons GH, Dzau VJ. Mechanisms of disease: the emerging concept of vascular remodeling. N Engl J Med 1994;330:1431-1438.

19. Lammie GA, Brannan F, Slattery J, Warlow C. Nonhypertensive cerebral small-vessel disease. Stroke 1997;28:2222-2229.

20. Nádasky T, Silva FG. Adult renal disease. In: Sternberg SS, Antonioli DA, Carter D, Mills SE, Oberman HA (Eds). Diagnostic surgical pathology, $3^{\text {rd }}$ Ed. Vol 2. Philadelphia: Lippincott Williams \& Wilkins, 1999:1701-1783.

21. Kaplan NM. Arterial hypertension. In Stern JH, editor-in-chief. Internal medicine, $5^{\text {th }}$ Ed. St Louis: Mosby, 1998:312-329.

22. Russell RWR. Observations on intracerebral aneurysms. Brain 1963;86:425-442.

23. Evans PH. Relation of longstanding blood-pressure levels to atherosclerosis. Lancet 1965;6:516-519.

24. Cole FM, Yates PO. Comparative incidence of cerebro-vascular lesions in normotensive and hypertensive patients. Neurology 1968;18:255-259.

25. Weller RO. Spontaneous intracranial haemorrhage, In: Adams JH, Duchen LW (Eds). Greenfield's neuropathology, $5^{\text {th }}$ Ed. New York: Oxford University Press, 1992:269-281.

26. Bots ML, Grobbee DE, Hofman A. High blood pressure in the elderly. Epidemiol Rev 1991;3:294-314.

27. MacSween RNM, Whaley K. Cardiovascular system. In: MacSween RNM, Whaley K (Eds). Muir's textbook of pathology, $13^{\text {th }}$ Ed. London: Edward Arnold, 1992:440-464.

28. Wiener J, Giacomelli F. Hypertensive vascular disease. In: Genest J, Kuchel O, Hamet P, Cantin M (Eds). Hypertension: physiopathology and treatment, $2^{\text {nd }}$ Ed. New York: McGraw-Hill, 1983; 498-524.

29. Smith JP. Hyaline arteriolosclerosis in spleen, pancreas, and other viscera. J Pathol Bact 1956;72:643-657.

30. Stehbens WE. Pathology of the cerebral blood vessels. Saint Louis: C.V. Mosby Company, 1972:1-59. 